\title{
A DEMOUNTABLE GIRDER - COLUMN JOINT
}

\author{
Aleš Polák \\ Czech Technical University in Prague, Faculty of Civil Engineering, Department of Building \\ Structures, Prague, Thákurova 7, Czech Republic; ales.polak@fsv.cvut.cz
}

\begin{abstract}
Traditional precast reinforced concrete structures are characterised by joints of individual components executed with the use of cement grouts or mortars, or by welding reinforcement. The joints produced in this way cannot be demounted in the case of need without damaging the precast components. Demountable precast structures with a long life cycle enable repeated assembly and demounting thus contributing to the saving of the basic input resources and the environment. The main feature of demountable precast structures are patent-protected joints which allow the assembly of the precast components without the necessity of using "wet" processes. The article addresses the characteristics of a demountable girder - column joint. It presents the results of static load tests carried out within extensive experimental research. To conclude, the article specifies the benefits and the applications of demountable structures.
\end{abstract}

\section{KEYWORDS} Column

Prefabrication, Demountable Structure, Sustainability, Experimental Research, Girder,

\section{INTRODUCTION}

Today's dynamically developing society poses increasing demands on the flexibility of buildings. However, traditional prefabricated systems, which are characterized by limited adaptability and relatively high demands in the case of a change in their use, are not in correspondence with this dynamic. Nearly all building reconfigurations due to a change in its use, or the building relocation caused by production, transportation or demographic requirements are associated with a complete or partial demolition of the currently existing systems, as the reuse of the components connected by traditional wet processes is very limited. Thus, numerous prefabricated buildings are demolished after reaching their moral obsolescence, which is usually much earlier than the end of their physical life span. As a result, additional costs related to a premature demolition and recycling of buildings are incurred. In addition to these costs, considerable amounts of energy are consumed during the whole process of a premature demolition of the structure, and a lot of environmentally harmful gases are released into the air.

A potential solution mitigating the adverse effects of standard precast reinforced concrete structures is the use of new structural systems with a long life cycle. The possibility of reusing demountable structures can make a significant contribution to environmental protection and, ultimately, can also significantly reduce the costs that would otherwise be needed mainly for the fabrication of new elements of the traditional precast reinforced concrete system.

A characteristic feature of the demountable system are mutual joints of individual precast components, which can be easily demounted, if necessary, without impairing the possibilities of the precast components' further use. In addition to their structural function, these joints should enable reassembly without the use of wet processes and, at the same time, they should be fully demountable. 


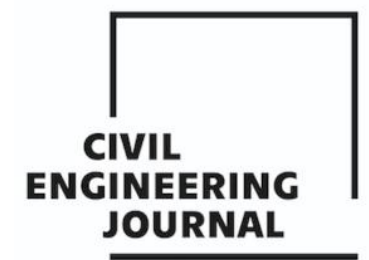

Article no. 68

THE CIVIL ENGINEERING JOURNAL 4-2021

The introduction should present the scientific background of the study and state clearly its objectives.

\section{ENVIRONMENTAL IMPACT OF REINFORCED CONCRETE STRUCTURES}

The crucial criterion governing the selection of a building structure these days, apart from the erection time, is usually its acquisition price, regardless of any other costs related to the use of the structure and its demolition. Within the environmental protection policy, building structures should be assessed in a complex way covering their entire life cycle. This means starting from the production of materials and the erection of the structure, through its operation and maintenance, to the subsequent demolition, including the recycling of materials or structural elements, considering even the number of construction elements subsequently deposited in landfills. Only after the assessment of all these aspects and their impacts on the environment, can a suitable building structure be objectively chosen [1].

The significance of the impact of concrete structures on the environment is evident mainly with regard to their production volumes, even though the amounts of harmful emissions associated with the production of one $\mathrm{kg}$ of concrete is relatively small compared to other structural materials. The per capita concrete production in developed countries ranges between 1.5 and 3 tonnes per year. This results in the huge consumption of non-renewable primary resources (for the production of cement, mining gravel and aggregate deposits), which leads to their total depletion. At the same time, considerable amounts of energy are consumed in obtaining these raw materials [2].

Compared to traditional precast reinforced concrete structures, demountable precast structures consume approximately the same amount of the primary building materials for their production. For some demountable structural components, the proportion of steel used may even be higher than for traditional structures. This is mainly due to the difference in the connection of both types of structures, where, in the case of demountable structures, the mutual joints of individual components are usually secured by connecting steel elements. Nevertheless, from the perspective of the overall comparison of the structure's life cycle costs, the potential higher proportion of steel in demountable structures is economically negligible.

By using demountable systems with a long life cycle, significant savings in the basic input resources can be achieved thus offsetting the current threat of mineral depletion. In terms of the amount of energy used, the most energy intensive phases of the life cycle of precast structures are the extraction of the necessary raw materials and the production of the precast components. By the reuse of demountable structures with a long life cycle, or a long design life, respectively, the amounts of energy required to provide the input materials and produce new components, but also the emissions of harmful gases, can be, to a significant extent, reduced.

The comparison in Figure 1 points out that in the case of reuse, demountable systems are significantly more ecological and less energy intensive compared to traditional precast systems. 


\section{CIVIL}

ENGINEERING

JOURNAL

THE CIVIL ENGINEERING JOURNAL 4-2021

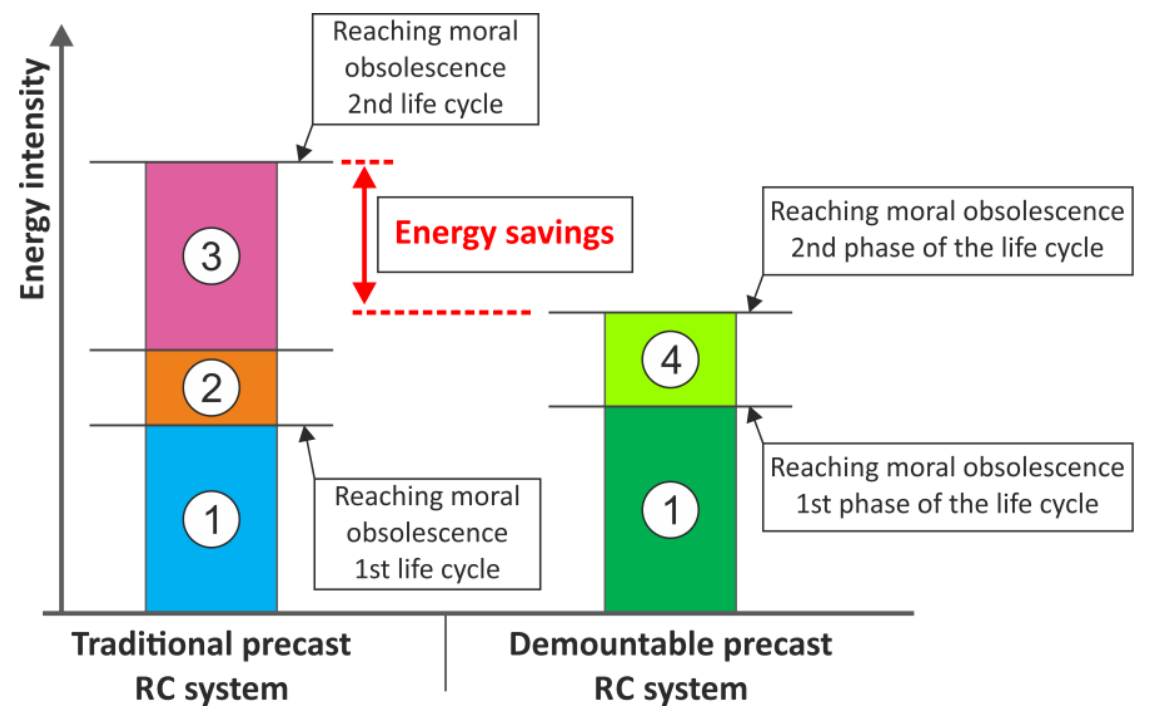

\section{LEGEND}

(1) Energy required for the production of elements for 1st phase / life cycle

(2) Energy required for the demolition and recycling of elements

Energy required for the production

3 of elements for 2 nd phase / life cycle

(4) Energy required for dismantling and production of any additional elements for the 2nd phase of the life cycle

Fig. 1 - Comparison of energy intensity for traditional and a demountable precast reinforced concrete system

At the same time, demountable structures consume only a fraction of the energy during their disassembly that would otherwise be needed for demolition. Moreover, individual components of the demountable structure can be reused. This construction method is very environmentally friendly compared to standard precast reinforced concrete structures, and, at the same time, it saves natural resources.

The constant pressure to reduce the energy and material intensity of newly designed buildings, together with the sustainability imperative in the construction industry, requires a new approach to the design of buildings covering the building's entire life cycle from its erection, through demolition to recycling and disposal at the end of the physical life of individual structural components and building parts. Material-saving solutions, together with low energy intensity implementation methods and design solutions creating the preconditions for the maximum return and recycling rate of the used materials and products, are one of the ways to achieve sustainable development [4].

The possibility of "recycling" reinforced concrete structures at the level of precast components results in significant energy and material savings mitigating the negative impact of the building industry on the environment. Compared specifically with the hitherto common recycling of building materials, the proposed solution of the "reuse of precast reinforced concrete components" represents a qualitatively higher degree of recycling. Not only is it not necessary to recycle precast reinforced concrete members, but it is also not necessary to spend new energy on the production of the basic materials mounted in new components. This advantage of the designed multi-purpose demountable system is becoming extremely important, especially with regard to the highly energy intensive production of the basic materials for the fabrication of reinforced concrete structures and their significant contribution to the ever-deteriorating environmental condition [5].

\section{DEMOUNTABLE GIRDER - COLUMN JOINT}

\section{Joint Characteristics}

A characteristic features of the demountable precast system are patent-protected dry demountable joints of load-bearing components. The main advantage of these joints is their potential reassembly and the disassembly of the supporting structure. An equally important benefit over the classic assembly of precast structures is the elimination of wet processes, i.e. connection of precast components in a "dry" way.

The design of joints is based on the production and assembly tolerances achievable at the current production technology level of precast reinforced concrete components (in the range of up 


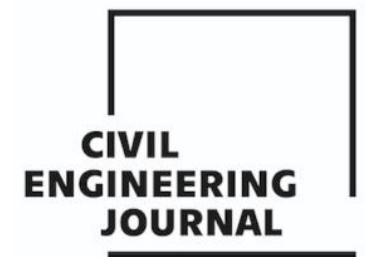

Article no. 68

THE CIVIL ENGINEERING JOURNAL 4-2021

to $\pm 5 \mathrm{~mm}$ in component dimensions) and the achievable assembly tolerances (in the range up to \pm $3 \mathrm{~mm}$ in component mounting). The resulting deviations of assembled structures generally depend on the precision of manufactured components, the precision of their alignment and mounting. In the case of demountable structures, the mounting precision, in particular, may apply to a significant extent [6].

The basic joint of the skeletal system is a demountable joint of a girder and a column ("girder - column" joint). This joint consists of anchor and mounting steel plates embedded in a precast column and a girder, and connecting steel elements additionally mounted during the assembly. The demountable "girder - column" joint is designed to enable easy assembly of the column structure using precast columns one or two to three storeys in height [7].

From the structural perspective, these are short brackets embedded in columns with girders mounted on them. The demountable joint (CZ patent No. 305454 B6) is composed of a special welded steel element, which enables a significantly fast mounting of the bracket using the principle of a self-locking interlocking joint (Figure 2). The disadvantage is higher labour intensity during the production of fittings, but, on the other hand, the need to use high-strength screws is eliminated, and the assembly time required for fastening the bracket is shortened. Another significant advantage of this type of joint is that the steel element can be mounted manually without the use of other tools (wrenches, nut runners).
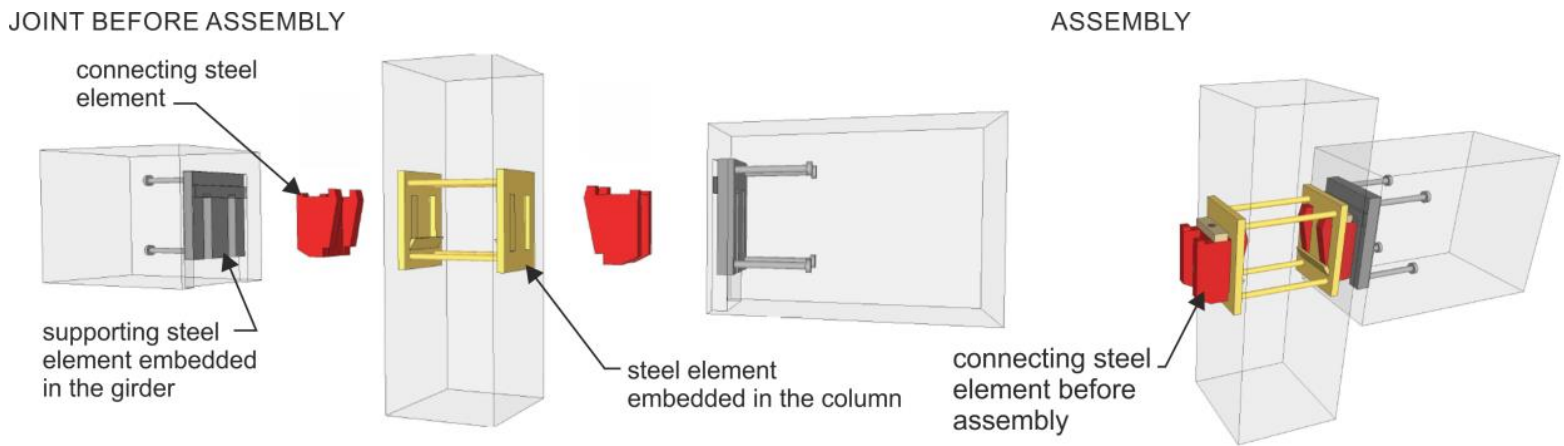

Fig. 2 - Scheme of the "girder - column" joint

Figure 3 displays the anchor and mounting steel plates for both versions of joints before their mounting into the concreting formwork. The fittings embedded in the column, including the connecting element (bracket), can be seen on the left, and the fittings embedded in the girder on the right.
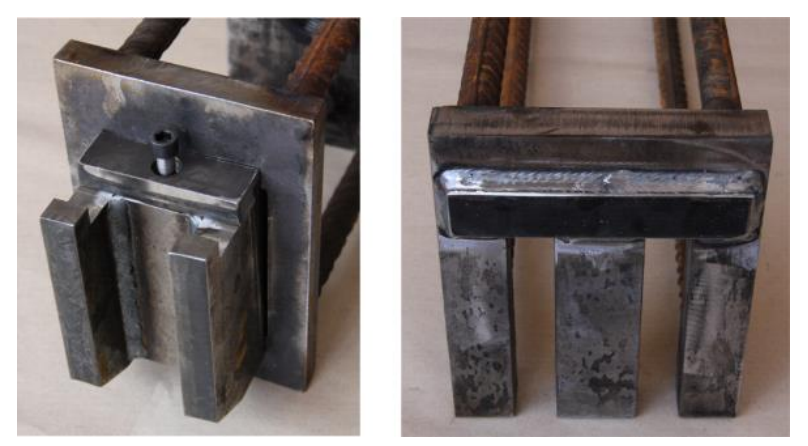

Fig. 3 - Steel fittings embedded in the column including the connecting element (on the left) and the girder (on the right) [3] 


\section{Experimental research into a demountable girder - column joint}

The experimental research into the essential parts of the load-bearing demountable precast system was carried out in cooperation with the Technical and Test Institute for Construction Prague, SOE. The subject of the experimental static load test of a section of the load-bearing precast skeletal system was the verification of the function and the load-bearing capacity of demountable girder column joints under flexural and shear loading. The test was divided into two parts - loading of the girder with bending and a shear force, and loading of the girder with a shear force only.

The test configuration (Figure 4) of the section of the demountable precast reinforced concrete system was composed of two columns with dimensions of $300 \times 300 \times 2000 \mathrm{~mm}$ and a girder embedded between them with cross-sectional dimensions of $300 \times 400 \mathrm{~mm}$ and $4800 \mathrm{~mm}$ in length. The girder was connected to the columns at an axial height of $1200 \mathrm{~mm}$. The columns were supported in steel footing and secured against shifting and rotation by means of wooden wedges. The steel footing was immovably fixed to the floor with screws. Steel load-distribution elements were mounted on the girder. The precast components were made of C45/55 concrete. The test configuration was fitted with 14 linear deformation sensors (LVDT), which recorded the horizontal and vertical deformations depending on the applied load.
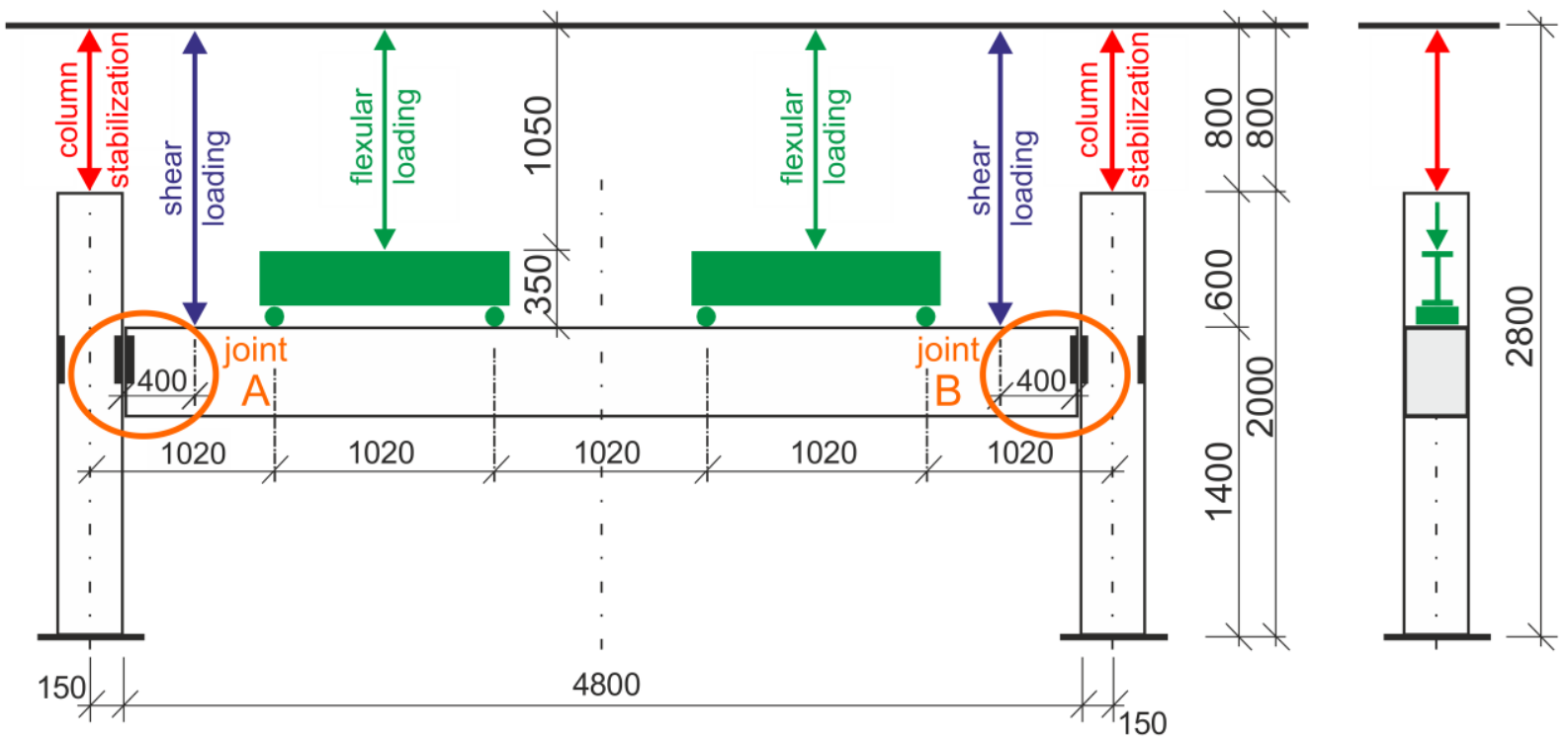

Fig. 4 - Scheme of the test configuration

\section{Flexural loading}

The test configuration was loaded by hydraulic presses mounted on a compression testing machine. The configuration was loaded step by step, first, the columns were loaded axially (constant load value of $2 \times 100 \mathrm{kN}$ ). The load on the girder was applied in individual steps of $2 \times 30 \mathrm{kN}$ with unloading to the basic value of $2 \times 30 \mathrm{kN}$. The gradual unloading was performed to determine permanent deformations. Under a load of $2 \times 210 \mathrm{kN}$, the first tensile cracks appeared in the area around the girder mid-span, and further crack development was recorded during the subsequent loading. Under a load of $2 \times 300 \mathrm{kN}$, the cracks on the lower face of the girder, in the middle of its length, reached $200-350 \mathrm{~mm}$ in length and $0.5-1.0 \mathrm{~mm}$ in width. The distance of individual cracks from each other ranged from 80 to $150 \mathrm{~mm}$. Under the ultimate load of the configuration, the concrete was crushed and the compressed reinforcement at the upper face of the girder mid-span warped. The total maximum achieved load value was $2 \times 440 \mathrm{kN}$ (load value without the weight of the girder and the load-distribution device). 
Article no. 68

CIVIL

ENGINEERING

JOURNAL

THE CIVIL ENGINEERING JOURNAL 4-2021
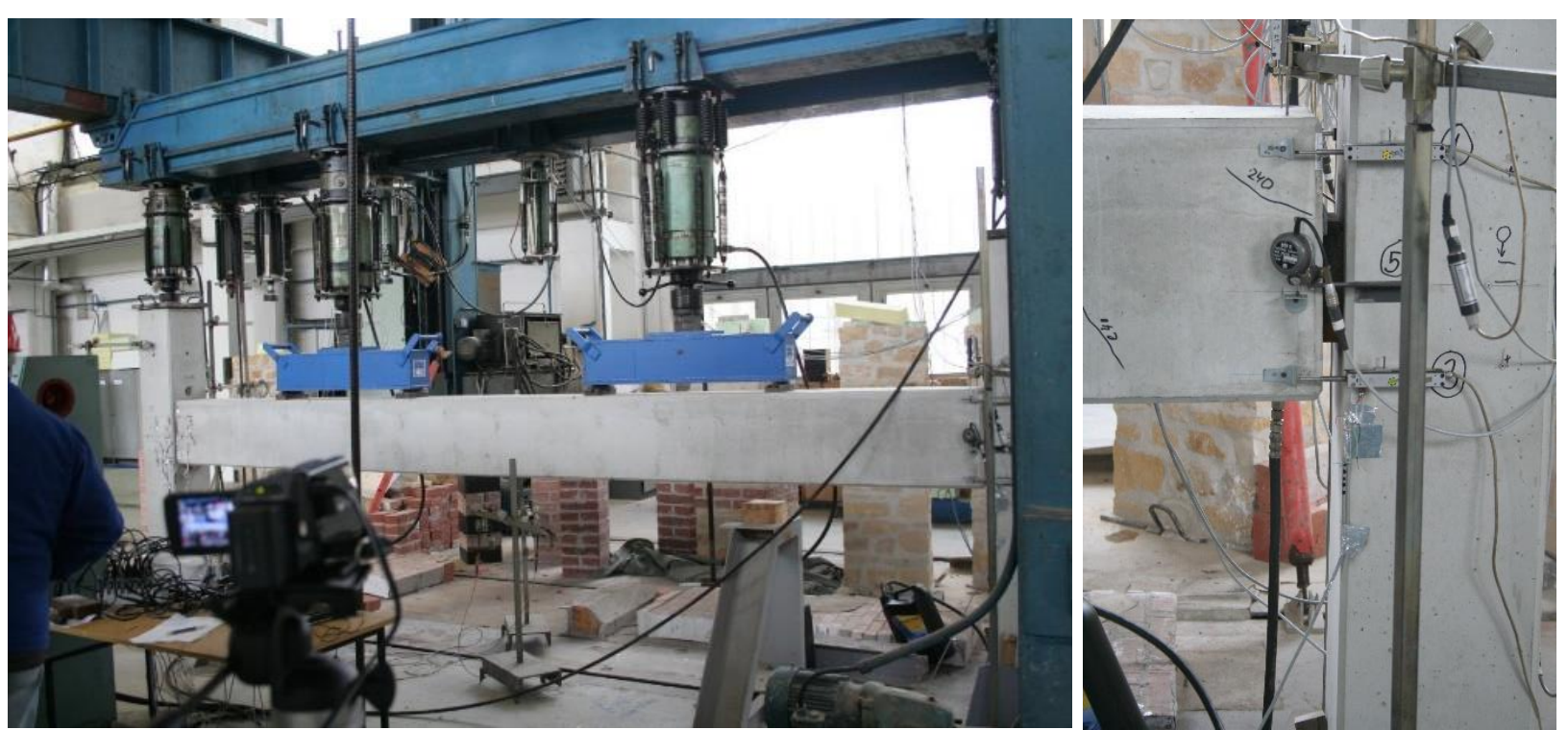

Fig. 5 - Test configuration (on the left) and the distribution of LVDT sensors at joint $B$ (on the right)

\section{Shear loading}

The test configuration (Figure 6) was loaded in successive steps in the same way as in the case of flexural loading. Under a load of $2 \times 360 \mathrm{kN}$, shear cracks due to flexural loading developed. Under increasing loads, these cracks continued to develop. Under a load of $2 \times 420 \mathrm{kN}$, cracks appeared on the upper face of the girder. The width of these cracks increased up to a limit load of 2 $\times 520 \mathrm{kN}$. Under this load, the concrete at the upper face of the girder failed, and the concrete reinforcement was torn out. The loading was subsequently terminated.
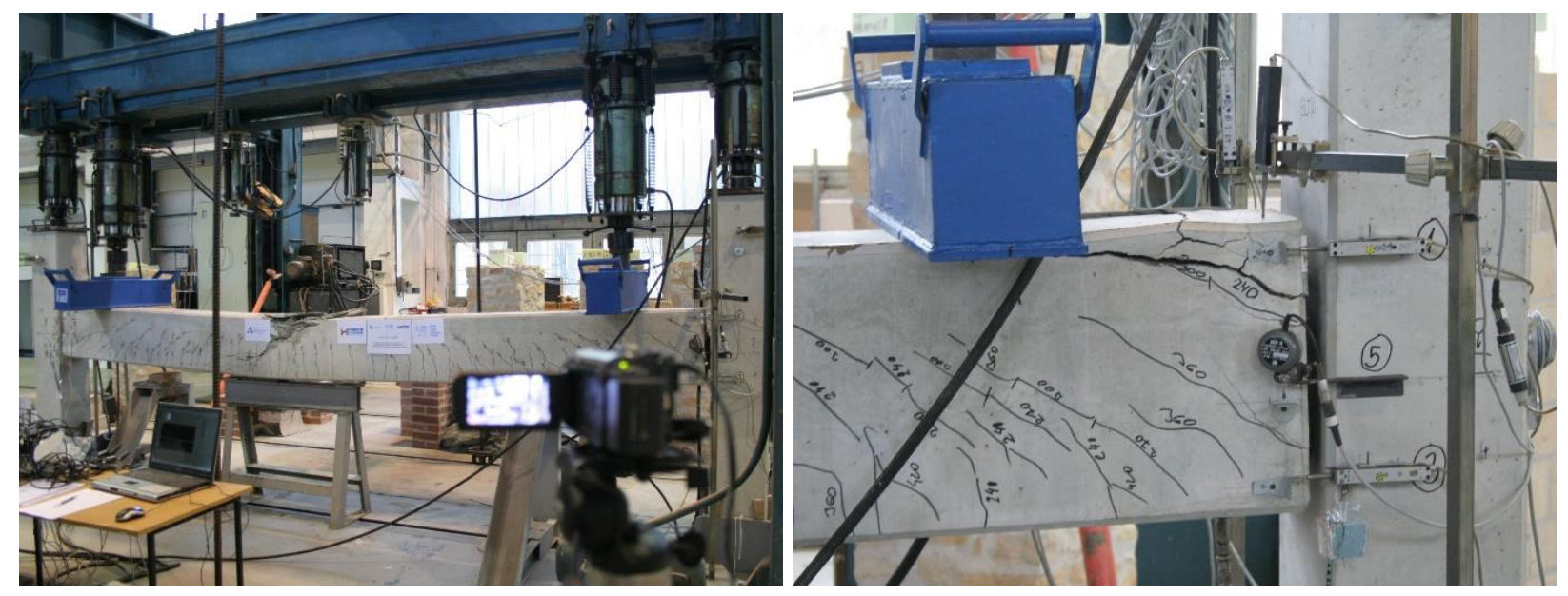

Fig. 6 - Test configuration (on the left), crack formation on the upper edge of the girder (on the right)

After the termination of loading, the girder was unloaded, and so were the columns. The type of girder failure (Figure 7) at both joints (A, B) was similar. The columns showed no failure in the joint area with the girder, and not even hairline cracks were recorded. 


\section{$\prod_{\text {EIVIL }}$ JOURNAL}

Article no. 68 THE CIVIL ENGINEERING JOURNAL 4-2021
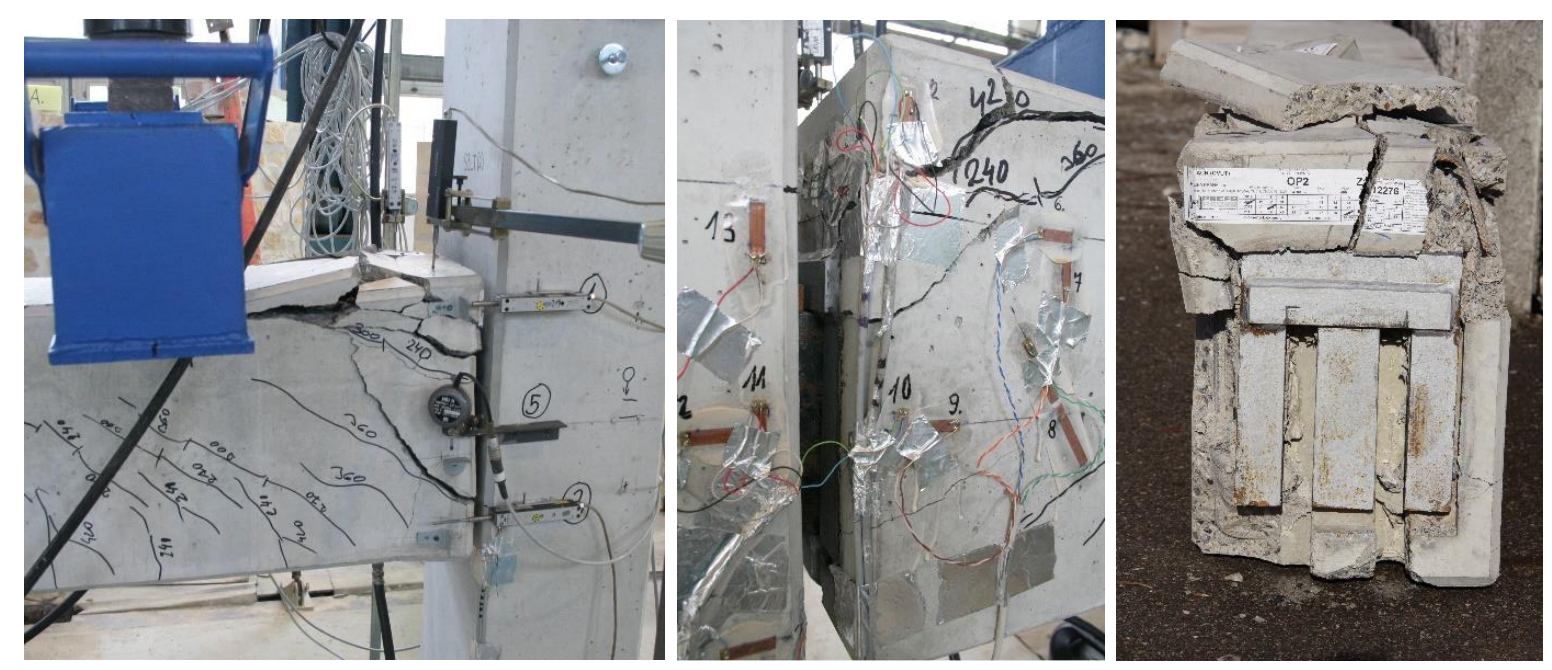

Fig. 7- Joint failure at reaching the ultimate loading

\section{Evaluation}

Under flexural loading, the measured deformations showed a linear pattern until a load of 2 $\times 300 \mathrm{kN}$ was reached, which exerted a bending moment on the girder of $423.3 \mathrm{kNm}$. The limit load was reached at a value of $2 \times 440 \mathrm{kN}$ - exerting the maximum bending moment on the girder (including the own weight of the girder and the load-distribution device) of $615.68 \mathrm{kNm}$, which is the bending moment corresponding to a continuous uniform load on the girder of $210.83 \mathrm{kN} / \mathrm{m}$. After reaching the maximum bending moment, the steel elements of the girder - column demountable joints did not show any signs of damage. Tensile cracks $0.15-0.25 \mathrm{~mm}$ wide with a mutual distance of approx. 80-100 $\mathrm{mm}$ were recorded in the joint area on the girder.

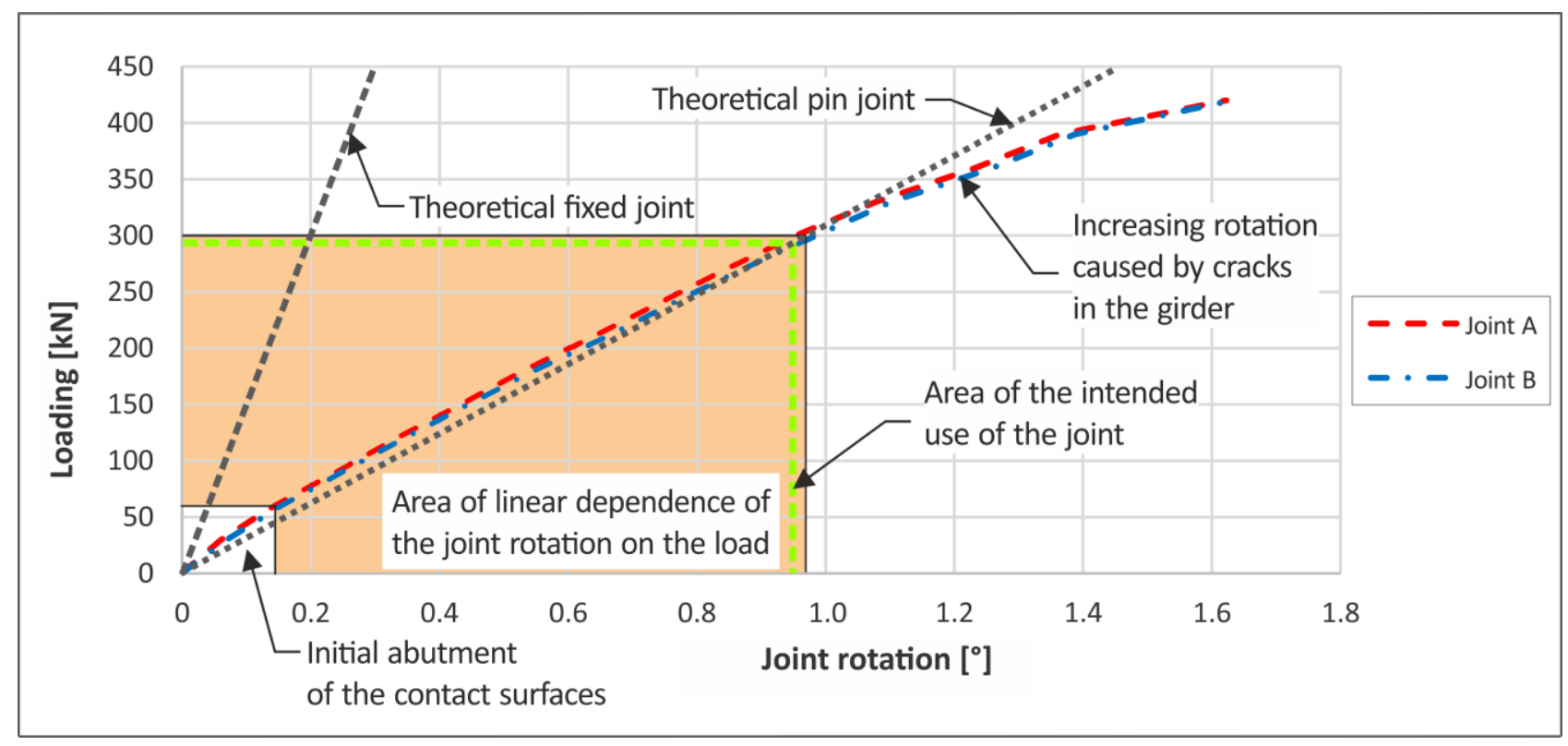

Fig. 8 - Dependence of girder - column joint rotation on loading and marking of key areas

The graph above (Figure 8) shows the dependence of the rotation of girder - column joints (deviation of the joint face from the vertical axis of the column) on the load. In the initial phase (up to a load of $2 \times 60 \mathrm{kN}$ ), the contact interfaces - steel surfaces of the connecting short bracket and steel surfaces of the fittings embedded inside the girder - abut on one another. Starting from this loading, the area of linear dependence of the joint rotation on the applied load (orange) follows - bounded by 


\section{$\prod_{\text {CIVIL }}$ JOURNAL}

Article no. 68

THE CIVIL ENGINEERING JOURNAL 4-2021

a load of $2 \times 300 \mathrm{kN}$. Thus, this linear area also includes the area of the intended use of the joint (the area boundary is marked by a green dashed line), which corresponds to the load (assumed permanent load of the floor structure, including the own weight of floor panels and the floor layer composition, of $5.5 \mathrm{kN} / \mathrm{m} 2$ and imposed load of $2.5 \mathrm{kN} / \mathrm{m} 2$ ) exerted by a floor structure with a maximum span of $8.4 \mathrm{~m}$.

It can be derived from the joint rotation - loading dependence pattern that from the structural perspective, the demountable girder - column joint behaves like a perfect hinge. At no load phase did a negative bending moment occur in this joint.

Under shear loading, the girder - column joint was loaded up to the shear force value per joint of $458.3 \mathrm{kN}$ (including the own weight of the girder and the load-distribution device), which corresponds to $86.7 \%$ of the ultimate load. Starting from this load, a significant development of cracks in the area above the embedded steel anchor elements was recorded in the girder. At the limit load, a total shearing force of $528.3 \mathrm{kN}$ acted on one joint (including the own weight of the girder and the load-distribution device). Under this load, the concrete in the upper part of the girder failed, and the steel anchor elements were torn out of the girder, but, at the same time, no cracks were recorded in the area of the embedded fittings in the column.

The graph below (Figure 9) displays the comparison of the experimentally identified loadbearing capacity of the demountable girder - column joint Vmax, exp and the theoretical design value of the load-bearing capacity of an identically reinforced concrete girder in shear VRd, theor (identified under ČSN EN 1992-1-1) with theoretical design values of the shear force corresponding to the load per joint for the considered grid of columns of $6.0 \times 6.0 \mathrm{~m}, 6.0 \times 7.2 \mathrm{~m}$ and $6.0 \times 8.4 \mathrm{~m}$ (the same permanent and imposed loads were considered as in the previous comparison of flexural loadbearing capacity).

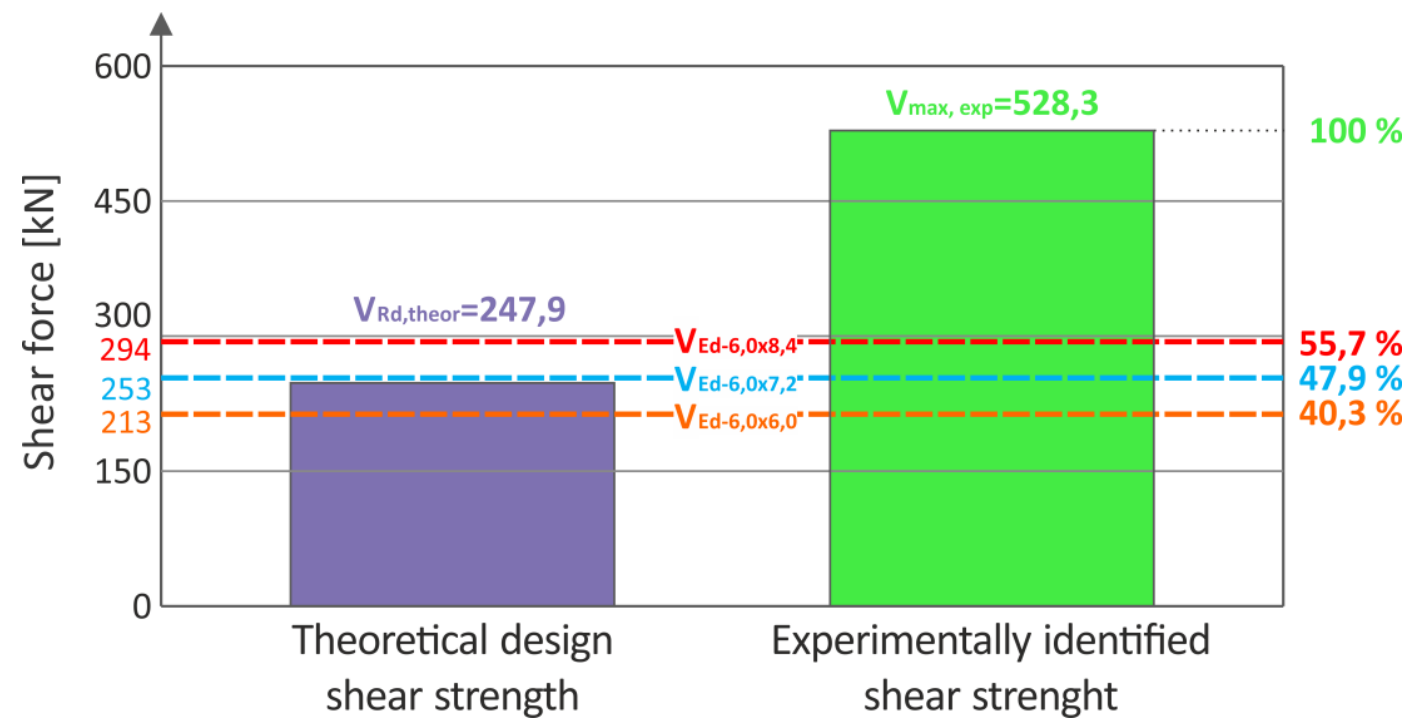

Fig. 9 - Comparison of the theoretical design and experimentally identified shear strength values with the design values of shear forces for the respective grids of columns

The theoretical design load-bearing capacity of the girder in shear was set at $247.9 \mathrm{kN}$ thus corresponding to $46.9 \%$ of the experimentally identified load-bearing capacity. Comparing the experimentally identified shear strength of the demountable girder - column joint with the theoretical design values of shear forces corresponding to the loading of the above grid of columns, it is evident that the design values of bending moments are in the range of $40.3 \%$ (bay of $6.0 \times 6.0 \mathrm{~m}$ ) to $55.7 \%$ (bay of $6.0 \times 8.4 \mathrm{~m}$ ).

No problems with the mounting or disconnection of individual precast components were recorded during the assembly of the test configuration and its subsequent disassembly. The assembly tolerances also proved to be satisfactory. 


\section{CONCLUSION}

\section{Demountable girder - column joint}

The demountable girder - column joint proved the functionality of the proposed design solution during both the assembly of the test configuration and its subsequent disassembly. At the same time, no problems during the mounting or disconnection of individual precast components were recorded. Thus, the assembly tolerances of the joint appeared to be satisfactory. The experimental verification of the joint has shown that:

- from the structural perspective, the girder - column joint can be classified as a perfect hinge;

- the joint's steel fittings embedded in the column remained free of any visible failure after reaching the ultimate loading;

- the steel fittings embedded in the girder remained free of any visible damage after reaching the ultimate loading - only indentation at the point of abutting surfaces was recorded;

- the joint failure under loading with a shear force occurred in the upper part of the girder due to exceeding the concrete tensile strength and simultaneous tear out of the concrete shear reinforcement;

- the experimentally identified shear strength of the joint was by $79.7 \%$ higher than the assumed maximum design load.

Therefore, the design of the joint's structural solution manifested sufficient load-bearing capacity for its assumed use.

\section{Benefits and application of demountable structures}

Demountable precast reinforced concrete structures meet the requirements of sustainable structures. Their main benefits in relation to the environment include the potential reuse of the precast components during one life cycle at a different time, place or a spatial layout thus reducing significantly the negative effects associated with the demolition and recycling of the existing structures and the manufacturing of new structures.

The basic difference of demountable precast reinforced concrete structures compared to the traditional precast system is the connection of individual components by means of discrete, usually steel, joints. The advantage of these demountable discrete joints of precast components is the possibility of their execution without welding and the use of "wet" processes and the related independence of climatic conditions. Another indisputable advantage is the acceleration of the whole assembly phase of the structure.

The necessary precondition for the application of demountable precast reinforced concrete structures, and the associated achievement of a favourable economic return but also an environmentally friendly policy, is their repeated use. Thus, the use of demountable systems will be desirable mainly in buildings with a premature moral obsolescence and a shorter functional life, such as buildings for preschool and primary education, accommodation and hotel facilities, buildings for production activities with an expected change in the production programme, but also for temporary buildings - start-up apartments, housing or civic amenities in places with a high temporary concentration of labour (long-term construction sites of primary importance - nuclear power plants, dams, etc.), or apartment buildings in areas affected by natural disasters, where the other advantages of demountable structures such as the speed of construction and independence of the assembly works on climatic conditions, will also undoubtedly apply.

\section{ACKNOWLEDGEMENTS}

The paper was written with support from the TA02010837 grant project "A Multipurpose Demountable Prefabricated Reinforced Concrete Building System with Controlled Joint Properties and Possibility of Repeated Use". The senior researcher of the project is prof. Ing. Jiři Witzany. DrSc. 
CIVIL

ENGINEERING JOURNAL

Ing. Radek Zigler, Ph.D., doc. Ing. Tomáš Čejka, Ph.D., Ing. Jiří Karas, CSc., Ing. Pavel Kokeš and Ing. Aneta Libecajtová have made significant contributions to this project.

\section{REFERENCES}

[1] Richard R. B., 2006. Industrialised, flexible and demountable bulding systems: quality, economy and sustainbility. The CRIOCM 2006 International Symposium, pp. 11.

[2] Procházka J. 2007. Environmentální aspekty navrhování betonových konstrukcí (ČVUT v Praze)

[3] Witzany J. et al., 2016. Závěrečná zpráva TAČR TA02010837 Víceúčelový demontovatelný

železobetonový stavební systém s řízenými vlastnostmi styků a možností opakovaných využití

[4] Polák A., 2015. Experimental Analysis of Demountable Precast Structure. In: Experimental Stress Analysis (České vysoké učení technické v Praze, Fakulta stavební), 321-324. ISBN 978-80-01-05734-6.

[5] Witzany J., Zigler R., Čejka T., Polák A. 2015. A demountable precast reinforced concrete building system of multi-story buildings. In: Proceedings of International Structural Engineering and Construction.

Fargo: ISEC Press, 219-224. ISBN 978-0-9960437-1-7. ISSN 2644-108X. DOI: 10.14455/ISEC.res.2015.138 [6] Witzany J., Zigler R., Čejka T., Polák A. 2020. Stavební systémy nové generace, 2. díl:

Demontovatelný stěnový systém. Časopis stavebnictví. 12(05): 44-50. ISSN 1802-2030

[7] Witzany J., Zigler R. 2020. Stavební systémy nové generace, 1. díl. Časopis stavebnictví. 12(04): 28-35. ISSN 1802-2030. 